\title{
Do ownership Concentration and Leverage Influence Firms’ Value? Evidence from Panel Data in Jordan
}

\author{
Dana M. AL-Najjar ${ }^{1}$ \\ ${ }^{1}$ Finance and Banking Department, Applied Science Private University, Amman, Jordan \\ Correspondence: Dana M. AL-Najjar, Finance and Banking Department, Applied Science Private University, \\ Postal code 11931, Post Office Box 166, Amman, Jordan. Tel: 962-777-476-164. E-mail: \\ dr.danaalnajjar@gmail.com
}

Received: December 9, 2015

doi:10.5539/ijbm.v11n6p262

\begin{abstract}
Elevating firm performance to optimal levels in order to maximize the firm value has been one of the concerns in corporate finance, due to the challenges accompanied with the failure in corporate control that led to successive financial scandals in the last decade worldwide. Hence, this study extends previous researches that were interested in the investigations of the effect of the key ownership structures in the emerging markets, by depending mainly on panel data analysis applied on a sample that consists of 83 non-financial firms listed at Amman Stock Exchange (ASE) during the period 2005-2013; to form two firm's value equations by relying on two dependent variables which are; Return on Assets (ROA), and Market to Book value (M/B). Regarding the explanatory variables there are four indicators representing various measures of ownership concentration depending mainly on the percentages of shares held by block holders in firms. In addition, the control variables in the two models consists of indicators for leverage; size, tangibility, business risk, and liquidity. The empirical findings are consistent with many prior studies that were applied on both Jordan and many emerging markets; in that, the concluding remarks support the existence of relationship between corporate concentration, leverage and firm's value.
\end{abstract}

Keywords: leverage, ownership concentration, firm value, Jordan, capital structure, emerging markets

\section{Introduction}

Enhancing firm performance so that it will maximize firm value has been one of the major debates in modern corporate finance for years that has not come to an end. Hence, to accomplish this optimal objective it is important to decide what the factors that affect firm's value are. Many studies, academic and professional, across the world have investigated many variables that may have influence on firm's decisions regarding capital structure, leverage, firm's activity, and liquidity. Recently and due to successive bankruptcy cases worldwide during financial crisis in both developed and developing countries many experts have been studying the causes and effects of such crisis on various economies. One of the major issues suggested is referred to agency problem and its effect on firm performance that has been discussed earlier by Berle and Means (1932), and extended in Jensen and Meckling (1976) study.

Furthermore, the empirical findings provided on the impact of ownership concentration, capital structure and the firm value have been ambiguous and not clearly specific. Hence, a growing body of the literature has applied different variables to explore the shape of their relationship with firm value.

In the same line, the corporate governance concept includes all mechanisms which seek to ensure that the resources are efficiently managed in firms and in the interests of the capital suppliers, mitigating the expropriation of resources by firm's managers (Shleifer \& Vishny, 1997). There is a various substantial body of research in the corporate governance literature that links ownership concentration and board characteristics with firm performance (see for example, Morck et al., 1988; McConnell \& Servaes, 1990). Accordingly, this paper focuses on one of the key characteristics regarding the corporate governance, namely, the degree of ownership concentration, and its effect on firm value that includes both indicators; Market to book ratio (M/B) and return on assets (ROA).

There is limited evidence regarding the investigation of corporate governance in emerging markets, which can be 
due to the availability of such information in these markets. Thus, this study aims to provide further investigation on the impact of both corporate governance, and capital structure on the firm's value. This is an important topic caused by the differences in economic, political, cultural, institutional landscapes, and corporate governance frameworks originating in developed countries that maybe considered to have limited applicability in developing countries (Bushman \& Smith, 2001).

The reminder of this paper is organized as follows section 2 explains literature review and hypothesis development, section 2 contains research design, Section 4 presents the results and Section 5 summarizes the conclusions and recommendations.

\section{Literature Review and Hypotheses Development}

This part of the study covers the major literature regarding the influence on firm's value by both ownership structure and capital structure. The early work in this area is referred to the study of Berle and Mean (1932) that pointed out the potential conflict of interest that may arise between both managers and dispersed shareholders caused by the lack of ownership interest by managers in the firm. In addition, Jensen and Meckling (1976) mainly asserted that when ownership and control are separated, the firm value is reduced due to added costs of monitoring and the participation of managers in activities that may not enhance an increase in firm value.

In contrast, Fama (1980), Demsetz (1983), and Fama and Jensen (1983, 1985) concluded that if managerial ownership rises that may have adverse effects in dealing with agency conflicts, thus it can lead to arise in managerial opportunism.

Demsetz (1983) on the other hand, argued that firms should not be affected by ownership structure. While other studies such as Shleifer and Vishny (1986), Morck et al. (1988); Short (1994); Kang and Shivadasan (1995); Gorton and Schmidt (1996); Gedojlovic and Shapiro (1998); Thomsen and Pedersen (2000); Pedersen and Thomsen (2003); and Frijins et al. (2008) confirmed the existence of direct relationship between both ownership concentration and the firm performance concluded by their empirical results.

Despite all the previous shapes of relationships concluded by studies, Stulz (1998) predicted that the relationship between firm performance and ownership concentration is concave. Moreover, various papers including studies for Morck et al. (1988); McConnell and Serves (1990); Hermalin and Weisbach (1991); and Holderness et al. (1999) all reported a negative relation in which firm's value rises when managerial ownership is low, in return reduction of firm's value is accompanied with high levels of managerial ownerships.

Studies at the end of the 90s were more interested in the degree of concentration in firms, both La Porta et al. (1999); and Becht and Roell (1999) results show that there is a high level of ownership concentration, hence less of dispersed shareholdings.

However, Johnson et al. (2000); Lehmans and Weigand (2000); Faccio and Lang (2002); Gugler and Weigand (2003) all these studies were concerned mainly with the existence of expropriation for the minority investors by the controlling owners, their empirical findings points out that large shareholders may have other objectives other than minor investors which in return lead to expropriation by minority investors.

Several studies such as Demsetz and Lehn (1985); Hermalin and Weisbach (1991); Loderer and Martin (1997); Cho (1998); Himmelberg et al. (1999); Demsetz and Villalonga (2001), Davies et al. (2005) focuses on the potential endogeneity of ownership structure in its relationship with firm performance. Their main findings support that there is no significant impact of ownership concentration on firm's performance. Contrary to these findings; Grosfeld (2006) supported a positive relationship between both ownership concentration and firm's value, with stronger impact when there is a control for the endogeneity of ownership. In addition, studies by Gursoy and Aydogan (2003); Seresht (2005); Javid and Iqbal (2010); Khoshkhoo et al. (2013) supported the relation between the concentration ownership and the firm performance.

On the other hand, various studies were interested in investigating the potential impact of leverage on firm value; the empirical findings were conflict, such as: Myers (1977) and McConnell and Servaes (1995) argued that the higher the growth opportunities, the lower the leverage rate should be, and thus in the presence of growth opportunities they support negative relationship between leverage and firm value. Consequently, other studies such as for example; Grossman and Hart (1982); Jensen (1986); Harris and Raviv (1991); De Andres et al. (2005); Castrillo et al. (2010); San-Martin and Duran-Encalada (2012) suggested that issuing a debt is a way to safe guarding the value of a firm, hence, managers are expected to lose control over the free cash flow. This overinvestment view applies when it is closely related to free cash flow and the firm has no growth opportunities (Jensen, 1986 \& 1993; Smith \& Watts, 1992; McConnell \& Servaes, 1995; Lang et al., 1996; Singh \& Faircloth, 2005). Therefore, according to this point of view, if the firm has no growth opportunities, then a positive 
relationship exists between both leverage and firm performance, since that the higher the leverage the more in-depth is the control undertaken by lenders (Lima \& López, 2010).

From emerging markets perspectives, Jafaar and Shawa (2009) indicated that the ownership concentration has a positive relationship on firm performance in Jordan, even though this result contradicts the findings of some developed countries studies (Demsetz \& Lehn, 1983; Himmelberg et al., 1999; Feris et al., 2003; Fich \& Shivdasani, 2006), but it is consistent with different emerging markets studies such as for Malaysia (Haniffa \& Hudaib, 2006), Tunisia (El Mehdi, 2007), India (Sarkar \& Sarkar, 2008), and other Jordanian studies (AL Khouri, 2006; Zeitun \& Tian, 2007). Thus, we hypothesize that:

H1: There is a significant positive relationship between both the ownership concentration and firm's value.

Moreover, the impact of ownership structure on capital structure is also a keen issue, because it underpins the link between both of them and firm's value. In addition, the existence of an effective monitoring by management may not be able to adjust leverage to their own interests as freely as they prefer. In that case firms with high levels of external block-holdings intends to increase their levels of debt ratio up to the level in which they reach near by the bankruptcy risk, consequently that will enhance firm's to start decreasing debt levels (Margaritis \& Psillaki, 2008).

Debt financing is a dominant factor in some emerging countries caused by its direct effect on financing and investing decisions, at both firm and country level (Reinhart, 2002; Erol, 2004; Abor \& Biekpe, 2007). Thus, corporate leverage can play a bilateral role on firm's value, depending mainly on the existence of firm's growth opportunities. Both studies by Masulis (1983) and Chowdhury et al. (2010) supported a positive correlation between both firm value and capital structure.

In addition to the previous discussion, more mixed results concerning the shape of relationship between both leverage and firm value is reported by Driffield et al. (2006) that was based on the study of Brailsford et al. (2002), hence, they suggest the existence of a relationship that is non-linear between both managerial share ownership and leverage. In other words, agency conflict decreases in firms that have low levels regarding managerial ownership in specific, and that in return will lead to a high leverage level. However, other authors such as Friend and Lang (1988), and Friend and Hasbrouck (1988) argue that if managerial ownership increases significantly, consequently, that will push firms to lower down their leverage levels, so that it can decrease the default risk thereby advocating a negative correlation between both managerial ownership and firm's leverage.

In the same vein, , Iturriaga and Crisóstomo (2010) detects the dominant role played by leverage, in which firm's value is expected to be negative for firms with growth opportunities, where as firms without growth opportunities is expected to have positive effect on firm's value, so there is a positive effect on the firms value without growth opportunities. Also, the empirical findings indicate that ownership concentration improves the firm's value through having a nonlinear effect. Likewise, the results of Reyna and Encalada (2012) demonstrate that the relevance of controlling shareholders on the value of the firm is various depending on growth opportunities of the firms. Therefore, the conclusions show that the level of leverage and ownership structure plays a keen role on firm value.

In line with Jensen and Meckling (1976) it is expected overall, that there is a negative effect of leverage on agency costs. This will lead to decreasing inefficiency levels and thereby to improve the value of the firm. On the other hand, there are many other studies that support the existence of positive relationship. Accordingly, this study adopts the following relationship between leverage and firm value:

$\mathrm{H}_{2}$ : There a significant positive relationship between Capital structure and firm's value.

\section{Research Design}

Panel Data Analysis method with cross section-time series information has been used to test our hypotheses and estimate the coefficients. The Time frame is from 2005-2013 and the sample includes all firms that fulfill the following conditions:

1- They have been accepted for listing at Amman Stock Exchange since the end of 2005, and their accounting calendar year ends at $31^{\text {st }}$ of December.

2- They are not among the firms with investment structures and holding companies.

3- During the research term, their shares have been actively traded in stock exchange and have no operating pause and their required information is accessible for calculating variables.

In respect to excluding financial firms from the sample, that is subsequent to their distinguished regulations and reporting standards in comparison to other sectors. Thereby, considering the above-mentioned conditions, 83 
non-financial firms were selected as statistical sample, and the data gathered from two sources; Amman Stock Exchange and Jordan's Depositary Center. In order to analyze and test the hypotheses, the variables were entered in STATA software.

This study depends on panel data to form firm's value equation rather than the well-known statistical technique Ordinary Least Square (OLS); and this is due to the fact that the OLS results may be biased for two main reasons: first, the unobserved heterogeneity of firms which may lead to correlation between ownership concentration and the firm's value; second, the simultaneity and potential reverse causality between both ownership and firm's value (Arellano \& Bover, 1990; Arellano, 1993; Himmelberg et al., 1999).

Since the key aspect of this study is to explore the effect of different variables on firm's value (V); one of the primary stages of analysis is the measurement of such variables, there are many proxies adopted in empirical studies to combine the firm value with growth opportunities (Berger \& Ofek, 1995; Gordon \& Myers, 1998; Danbolt et al., 2002; Adam \& Goyal, 2008; Iturriaga \& Crisóstomo, 2010). Although a number of different measurements are used as a proxy for firm value and growth opportunities, the commonly used includes Return on Assets ratio (ROA), the Price-Earnings ratio (P/E), and Market to Book (MB) ratios. Adam and Goyal (2008), and Iturriaga and Crisóstomo (2010) concludes that Market to book (M/B) ratio, does contain information content regarding the investment opportunities in firms.

Consequently, the foundational measure of firm value as a dependent variable is a version of two of the most frequently used indicators of firm's value in previous research that includes; Market to book ratio (M/B) and Return on Assets (ROA). Not only do these measures provide us with the most efficient proxies, but also it allows our results to be compared with previous literature (Morck et al., 1988; Lang \& Stulz, 1994; McConnell \& Servaes, 1990, 1995; Servaes, 1996; Cho, 1998; Chi, 2005; King \& Santor, 2008; Berkman et al., 2009; Iturriaga \& Crisóstomo, 2010). Definition of MB is the ratio of the firm's market value to its book value, and return on assets (ROA) is defined as the ratio of accounting profit to the value of Assets. The rationale is that the higher the MB and ROA, the higher the book value due to growth opportunities and the better is the firm performance, that all in return will affect the firm value positively.

Regarding the explanatory variables; the first measure of concentration is the percentage of shares held by the largest block holder $\left(\mathrm{C}_{1}\right)$. Second, the sum of holdings of the largest and the second largest block holder $\left(\mathrm{C}_{2}\right)$, also third, is accumulation of holdings of the three largest block holders $\left(\mathrm{C}_{3}\right)$. And the final measure is the same as that used in much of the previous studies on this topic: that is, the sum of all five percentages or high levels of ownership by blockholders $\left(\mathrm{C}_{\text {all }}\right)$.

For capital structure; the debt measurement is the leverage ratio (LEV); defined as the total debt divided by total owners' equity (D/E). Also, we include in the model firm-level control variables: Size defined as Log (total assets), tangibility defined as fixed assets divided by total assets, liquidity defined as current ratio measured by current assets divided by current liabilities, and business risk defined as standard deviation of return on equity $\left(\sigma_{\text {ROEit }}\right)$ (Earl et al., 2003; Frank \& Goyal, 2003; Jermias, 2007; Iturriaga \& Crisóstomo, 2010; Reyna \& Encalada, 2012). Our models hence are as follows:

$$
\begin{aligned}
& V_{l}=\beta_{0}+\beta_{1} C_{i t}+\beta_{2} . L E V_{i t}+\beta \text {. Control variables } i t+\varepsilon_{i t} . \\
& V_{2}=\beta_{0}+\beta_{1} \cdot C_{i t}+\beta_{2} . L E V_{i t}+\beta \text {. Control variables } i t+\varepsilon_{i t} .
\end{aligned}
$$

Where $\mathrm{i}$ refer to the firm and $\mathrm{t}$ refers to time. $\varepsilon_{\mathrm{it}}$, is the random error term, controls the error in measuring the variables and omitting some relevant explanatory variables.

\section{Empirical Findings}

\subsection{Descriptive Analysis}

Before presenting the empirical findings of the regression analysis, Table 1 presents the basic descriptive statistics. The sample mean of market to book (MB) is 1.745. The mean value for the ownership concentration is around $55 \%$, this reflects a relatively high level of concentrated ownership in Jordanian firms. On the other hand, the leverage ratio is approximately $76 \%$ which indicates that Jordanian firms depend heavily on debt in their capital structures. Finally for current ratio it is around 4 which indicates that current assets are 4 times current 'liabilities and tangibility shows that $42 \%$ of total assets are fixed assets. 
Table 1. Descriptive analysis

\begin{tabular}{lllll}
\hline Variable & Mean & Std. Dev. & Min & Max \\
\hline MTB & 1.745 & 1.138 & 0.000 & 8.165 \\
ROA & 0.037 & 0.103 & -0.499 & 0.557 \\
C1 & 0.427 & 0.224 & 0.000 & 1.000 \\
C2 & 0.480 & 0.242 & 0.000 & 1.000 \\
C3 & 0.489 & 0.245 & 0.000 & 1.000 \\
C all & 0.553 & 0.350 & 0.000 & 1.974 \\
DE & 0.764 & 1.462 & 0.001 & 17.094 \\
CR & 4.358 & 39.859 & 0.008 & 990.119 \\
SIZE & 16.879 & 1.359 & 13.221 & 20.975 \\
Tang. & 0.420 & 0.249 & 0.000 & 0.973 \\
BR & 0.118 & 0.126 & 0.007 & 0.786 \\
\hline
\end{tabular}

In order to detect the multicollinarity problem that may exist between the variables in the regression models, it is important to review the correlation coefficients between the selected variables. Table 2 presents the correlation matrix, and as expected the highest correlation is between the indicators of the ownership concentration $\left(\mathrm{C}_{1}, \mathrm{C}_{2}\right.$, $\mathrm{C}_{3}$, and $\mathrm{C}_{\mathrm{all}}$ ). This is because these variables overlap in their definitions included separately in the models. Furthermore, the correlation between the remaining variables included in the model is considered to be not high, accordingly the variables are suitable to build a panel regression analysis. Hence, multicolinearity is not an issue in our models.

Table 2. Correlation matrix

\begin{tabular}{|c|c|c|c|c|c|c|c|c|c|}
\hline & $\mathrm{C}_{1}$ & $\mathrm{C}_{2}$ & $\mathrm{C}_{3}$ & $\mathrm{C}_{\text {all }}$ & $\mathrm{DE}$ & $\mathrm{CR}$ & SIZE & Tang. & B.RISK \\
\hline $\mathrm{C}_{1}$ & 1.000 & & & & & & & & \\
\hline $\mathrm{C}_{2}$ & 0.948 & 1.000 & & & & & & & \\
\hline $\mathrm{C}_{3}$ & 0.935 & 0.997 & 1.000 & & & & & & \\
\hline $\mathrm{C}_{\text {all }}$ & 0.642 & 0.639 & 0.627 & 1.000 & & & & & \\
\hline $\mathrm{DE}$ & 0.057 & 0.068 & 0.081 & 0.047 & 1.000 & & & & \\
\hline $\mathrm{CR}$ & -0.051 & -0.053 & -0.054 & -0.033 & -0.039 & 1.000 & & & \\
\hline SIZE & 0.119 & 0.186 & 0.207 & 0.100 & 0.232 & -0.105 & 1.000 & & \\
\hline Tang. & -0.009 & -0.058 & -0.061 & 0.006 & -0.048 & -0.012 & 0.016 & 1.000 & \\
\hline $\mathrm{BR}$ & 0.008 & 0.040 & 0.045 & 0.141 & 0.306 & -0.036 & 0.040 & -0.101 & 1.000 \\
\hline
\end{tabular}

\subsection{Regression Results}

The results of the panel data analysis are displayed in both Table 3 and 4, each represents estimating the firm's value model with two various proxies of the dependent variable and four indicators of concentration $\left(\mathrm{C}_{1}, \mathrm{C}_{2}, \mathrm{C}_{3}\right.$, and $\mathrm{C}_{\text {all }}$.

The Hausman test reveals the importance of the fixed effect model in comparison to the random and the pooled models. Hence, it is necessary within group estimation method, in order to deal with the constant unobservable heterogeneity.

The main findings for both regression models can be explained as follows; for M/B ratio and ROA models the largest block holding, $\mathrm{C}_{1}$, is estimated to have a statistical positive significance effect on firm value at the 1 percent level of significance for $\mathrm{M} / \mathrm{B}$ model, and it is statistically insignificant for ROA model. In addition, the point estimate for the coefficient of $\mathrm{C}_{2}$ is much smaller in both equations, and it is statistically insignificant for ROA model and significant at the 5 percent level for M/B model. The coefficients of $\mathrm{C}_{3}$ and $\mathrm{C}_{\text {all }}$ are statistically significant at both significance level of 5 percent and 1 percent respectively in favor of $\mathrm{M} / \mathrm{B}$ model. Also, $\mathrm{C}_{3}$ and $\mathrm{C}_{\text {all }}$ are statistically significant for the ROA model.

Hence, as expected ownership concentration is found to exert a positive influence on accounts-based performance and firm's value. These results confirm our first hypothesis. In accordance this result is consistent with earlier empirical studies on Jordanian market (Al-Khouri, 2006; Zeitun \& Tian, 2007; Jaafar \& El-Shawa, 2009). Thus, this supports the hypothesis that more highly concentrated ownership tends to improve the firm value, by alleviating free-rider problems and via enhancing firm's over sighting (Shleifer \& Vishny, 1986). 
Table 3. Panel data regression output for MTB model

\begin{tabular}{|c|c|c|c|c|c|c|c|c|c|c|c|c|}
\hline \multirow[b]{2}{*}{ MTB } & \multicolumn{3}{|c|}{ Model 1} & \multicolumn{3}{|c|}{ Model 2} & \multicolumn{3}{|c|}{ Model 3} & \multicolumn{3}{|l|}{ Model 4} \\
\hline & Coef. & $\mathrm{t}$ & $\mathrm{P}>|\mathrm{t}|$ & Coef. & $\mathrm{T}$ & $\mathrm{P}>|\mathrm{t}|$ & Coef. & $\mathrm{t}$ & $\mathrm{P}>|\mathrm{t}|$ & Coef. & $\mathrm{t}$ & $\mathrm{P}>|\mathrm{t}|$ \\
\hline $\mathrm{C} 1$ & 0.769 & 2.680 & 0.008 & & & & & & & & & \\
\hline $\mathrm{C} 2$ & & & & 0.678 & 2.410 & 0.016 & & & & & & \\
\hline C 3 & & & & & & & 0.691 & 2.480 & 0.013 & & & \\
\hline $\mathrm{C}$ all & & & & & & & & & & 0.973 & 4.030 & 0.000 \\
\hline $\mathrm{DE}$ & 0.102 & 2.710 & 0.007 & 0.107 & 2.850 & 0.005 & 0.107 & 2.860 & 0.004 & 0.091 & 2.440 & 0.015 \\
\hline $\mathrm{CR}$ & 0.000 & 0.520 & 0.602 & 0.000 & 0.480 & 0.634 & 0.000 & 0.480 & 0.632 & 0.000 & 0.610 & 0.539 \\
\hline SIZE & -1.056 & -10.760 & 0.000 & -1.063 & -10.830 & 0.000 & -1.063 & -10.850 & 0.000 & -1.058 & -10.980 & 0.000 \\
\hline Tang. & -1.672 & -4.750 & 0.000 & -1.712 & -4.870 & 0.000 & -1.711 & -4.870 & 0.000 & -1.687 & -4.830 & 0.000 \\
\hline BR & -7.834 & -1.150 & 0.249 & -7.606 & -1.120 & 0.263 & -7.607 & -1.120 & 0.263 & -8.039 & -1.200 & 0.230 \\
\hline Cons. & 20.798 & 11.350 & 0.000 & 20.904 & 11.400 & 0.000 & 20.894 & 11.410 & 0.000 & 20.676 & 11.470 & 0.000 \\
\hline \# of obs. & 627 & & & 627 & & & 627 & & & 620 & & \\
\hline R-sq. & 0.2326 & & & 0.2307 & & & 0.2312 & & & 0.2490 & & \\
\hline
\end{tabular}

Furthermore, regarding the relationship between capital structure (leverage) and firm's value the following results are found; the first model with $\mathrm{M} / \mathrm{B}$ all variables including $\left(\mathrm{C}_{1}, \mathrm{C}_{2}, \mathrm{C}_{3}\right)$ were found to be positively significant at $1 \%$ significance level except for $\mathrm{C}_{\text {all }}$ it is significant at $5 \%$ level, which suggests that debt is disciplinary and that the firm value raises by reducing the free cash flow through preventing managers from incurring wasteful costs. Therefore, these empirical findings confirm the second hypothesis of this study, as well as it is consistent with the following studies: Jaafar and El-Shawa (2009), Iturriaga and Crisóstomo (2010), and Reyna and Encalada (2012). On the other hand, the second model with ROA as the dependent variable, all four models adopting different indicators of ownership concentration supports the negative relationship at $1 \%$ significance level between leverage and firm's value, and that is consistent with Iturriaga and Crisóstomo (2010) study.

Regarding the control variables (size, business risk, tangibility, and current ratio), they all have the same findings for both models with different indicators of ownership concentration. In M/B model as dependent variable the size and tangibility is negatively significant at $1 \%$ significance level consistent with both Javid and Iqbal (2010), and Reyna and Encalada (2012), for leverage and current ratio it is insignificant. However, for the ROA model both current ratio and sizes are positively insignificant consistent with Jaafar and El-Shawa (2009) study, on the other hand, both tangibility and business risk are found to be negatively significant.

Table 4. Panel data regression output for ROA model

\begin{tabular}{|c|c|c|c|c|c|c|c|c|c|c|c|c|}
\hline \multirow[b]{2}{*}{ ROA } & \multicolumn{3}{|c|}{ Model 1} & \multicolumn{3}{|c|}{ Model 2} & \multicolumn{3}{|c|}{ Model 3} & \multicolumn{3}{|c|}{ Model A } \\
\hline & Coef. & $\mathrm{t}$ & $\mathrm{P}>|\mathrm{t}|$ & Coef. & $\mathrm{T}$ & $\mathrm{P}>|\mathrm{t}|$ & Coef. & $\mathrm{t}$ & $\mathrm{P}>|\mathrm{t}|$ & Coef. & $\mathrm{t}$ & $\mathrm{P}>|\mathrm{t}|$ \\
\hline $\mathrm{C} 1$ & 0.769 & 2.680 & 0.008 & & & & & & & & & \\
\hline $\mathrm{C} 2$ & & & & 0.678 & 2.410 & 0.016 & & & & & & \\
\hline C 3 & & & & & & & 0.691 & 2.480 & 0.013 & & & \\
\hline $\mathrm{C}$ all & & & & & & & & & & 0.973 & 4.030 & 0.000 \\
\hline $\mathrm{DE}$ & -0.102 & 2.710 & 0.007 & -0.107 & 2.850 & 0.005 & -0.107 & 2.860 & 0.004 & -0.091 & 2.440 & 0.015 \\
\hline CR & 0.000 & 0.520 & 0.602 & 0.000 & 0.480 & 0.634 & 0.000 & 0.480 & 0.632 & 0.000 & 0.610 & 0.539 \\
\hline SIZE & 1.056 & -10.760 & 0.000 & -1.063 & 10.830 & 0.000 & -1.063 & -10.850 & 0.000 & -1.058 & -10.980 & 0.000 \\
\hline Tang. & -1.672 & -4.750 & 0.000 & -1.712 & -4.870 & 0.000 & -1.711 & -4.870 & 0.000 & -1.687 & -4.830 & 0.000 \\
\hline BR & -7.834 & -1.150 & 0.249 & -7.606 & -1.120 & 0.263 & -7.607 & -1.120 & 0.263 & -8.039 & -1.200 & 0.230 \\
\hline Cons. & 20.798 & 11.350 & 0.000 & 20.904 & 11.400 & 0.000 & 20.894 & 11.410 & 0.000 & 20.676 & 11.470 & 0.000 \\
\hline \# of obs. & 627 & & & 627 & & & 627 & & & 620 & & \\
\hline R-sq. & 0.2326 & & & 0.2307 & & & 0.2312 & & & 0.2490 & & \\
\hline
\end{tabular}

For the aim of double checking the robustness of our empirical findings, various robustness checks were used, that includes; logit analysis, between effects modelling, lagged regression modelling (for both profitable vs. non-profitable firms). The results came up to be not significantly different than what is reported in this study, also due to parsimony these models were not reported. 


\section{Conclusions}

This paper aims to assess the relation between governance mechanisms and firm's value, focusing on ownership concentration. Thus, the study extend prior research in the extant literature and investigate the roles of key ownership structures in the context of an emerging market which is characterized to be a weak market for corporate control and more concentrated equity ownership.

The empirical results delivered in this study remained in-line with various earlier studies that depended on a sample taken either from Jordanian firms or from emerging economies firms as well, as for Jordan's case for example studies by Al-Khouri (2006), Zeitun and Tian (2007), and Jaafar and El-Shawa (2009), as for emerging markets the studies of; for example Barberis et al. (1996); Xu and Wang (1997); Claessens and Djankov (1999), their empirical results are consistent with our results. Accordingly, our empirical findings provides extra proof in that firm's ownership concentration augment firm's value through enhancing surveillance and mitigating the problems regarding the free riders in firms. Thus it is expected that the increase in the levels of ownership is considered to be a compensation for the decreased levels of investor protection that exists in emerging markets in general (Reyna \& Encalada, 2012) and Jordan in specific. To make our story short our results confirm the relationship between corporate concentration, leverage and firm's value.

The conclusions previously discussed can enlighten future research directions through adding up several issues such as for example; firstly, other corporate governance mechanisms in assessing firm value and performance. Secondly, the dimension of the sample could be increased by including a longer period of time. Moreover, this study is limited to firms domiciled in Jordan; perhaps future research can embark on comparing various corporate governance practices across multiple Middle Eastern countries, which generally share similar economic and institutional landscapes.

\section{References}

Ahmed, K., Hossain, M., \& Adams, M. B. (2006). The Effects of Board Composition and Board Size on the in formativeness of Annual Accounting Earnings. Corporate Governance: An International Review, 14(5), 418-431.

Al-Khouri, R. (2006). Corporate Governance and Firm Value in Emerging Markets: The Case of Jordan. Journal of Transnational Management, 12(1), 25-49. http://dx.doi.org/10.1300/j482v12n01_03

Attiya, Y. J., \& Robina, I. (2010). Corporate Governance in Pakistan: Corporate Valuation, Ownership and Financing, Governance Working Papers 22830. East Asian Bureau of Economic Research.

$\mathrm{Au}, \mathrm{K}$. , Peng, M. W., \& Wang, D. (2000). Interlocking Directorates, Firm Strategies, and Performance in pre-1997 Hong Kong: Towards a Research Agenda. Asia Pacific Journal of Management, 17(1), 28-47. http://dx.doi.org/10.1023/A:1015432819596

Aziz, J., \& Mahmoud, E. S. (2009). Ownership concentration, board characteristics and performance: Evidence from Jordan. In T. Mathew \& U. Shahzad (Eds.), Accounting in Emerging Economies (Volume 9, pp. 73-95). http://dx.doi.org/10.1108/s1479-3563(2009)0000009005

Baliga, B., Moyer, C., \& Rao, R. (1996). CEO Duality and Firm Performance: What's the Fuss? Strategic Management Journal, 41-53. http://dx.doi.org/10.1002/(SICI)1097-0266(199601)17:1<41::AID-SMJ784>3.0.CO;2-\#

Barberis, N., Boycko, M., Shleifer, A., \& Tsukanova, N. (1997). How Does Privatization Work? Evidence from the Russian Shops. Journal of Political Economy, 104(4), 764-790. http://dx.doi.org/10.1086/262042

Barclay, M. J., \& Holderness, C. G. (1989). Private Benefits from Control of Public Corporations. Journal of Financial Economics, 23(2), 371-395. http://dx.doi.org/10.1016/0304-405X(89)90088-3

Beasely, M. S. (1996). An Empirical Analysis of the Relation between the Board of Director Composition and Financial Statement Fraud. The Accounting Review, 71, 443-465.

Beiner, S., Drobetz, W., Schmid, F., \& Zimmermann, H. (2004). Is Board Size an Independent Corporate Governance Mechanism? Kyklos, 57(3), 327-356. http://dx.doi.org/10.1111/j.0023 5962.2004.00257.x

Berg, A., \& Nenova, T. (2004). Report on the Observance of Standards and Codes (ROSC): Corporate Governance Country Assessment-Jordan. World Bank-IMF.

Bhattacharya, P. S., \& Graham, M. (2007). Institutional Ownership and Firm Performance: Evidence from Finland. Working paper.

Blackburn, V. L. (1994). The Effectiveness of Corporate Control in the U.S. Corporate Governance, An 
International Review, 2(4), 196-202. http://dx.doi.org/10.1111/j.1467-8683.1994.tb00078.x

Brickley, J. A., Lease, R. C., \& Smith, C. W. (1988). Ownership structure and voting on anti-takeover amendments. Journal of Financial Economics, 26, 267-291. http://dx.doi.org/10.1016/0304-405X(88)90047-5

Brickley, J., Coles, J., \& Jarrell, G. (1997). Leadership Structure: Separating the CEO and Chairman of the Board. Journal of Corporate Finance, 3, 189-220. http://dx.doi.org/10.1016/S0929-1199(96)00013-2

Brown, W. O., \& Maloney, M. T. (1999). Exit, Voice and the Role of Corporate Directors: Evidence from Acquisition Performance. Working paper, University of Virginia.

Bushman, R. M., \& Smith, A. J. (2001). Financial Accounting Information and Corporate Governance. Journal of Accounting and Economics, 32(1-3), 237-333. http://dx.doi.org/10.1016/S0165-4101(01)00027-1

Chen, J., Blenman, L., \& Chen, D. (2008). Does institutional ownership create values? New Zealand case. Quarterly Journal of finance and accounting, 47(4), 109-132.

Chen, S., Evans, J., \& Nagarajan, N. J. (2008). Board Size and Firm Performance: The Moderating Effects of the Market for Corporate Control. Review Quantitative Financial Accounting.

Chen, Z., Cheung, Y. K., Stouraitis, A., \& Wong, W. S. (2005). Ownership Concentration, Firm Performance, and Dividend Policy in Hong Kong. Pacific-Basin Finance Journal, 13(4), 431-449. http://dx.doi.org/10.1016/j.pacfin.2004.12.001

Cho, M. H. (1998). Ownership Structure, Investment, and the Corporate Value: An Empirical Analysis. Journal of Financial Economics, 47, 103-121. http://dx.doi.org/10.1016/S0304-405X(97)00039-1

Claessens, S. (1997). Corporate Governance and Equity Prices: Evidence from the Czech and Slovak Republics. Journal of Finance, 52(4), 1641-1658. http://dx.doi.org/10.1111/j.1540-6261.1997.tb01124.x

Claessens, S., \& Djankov, S. (1999). Ownership Concentration and Corporate Performance in the Czech Republic. Journal of Comparative Economics, 27, 498-513. http://dx.doi.org/10.1006/jcec.1999.1598

Coffee, J. (1999). The Future as History: The Prospects for Global Convergence in Corporate Governance and its Implications. Northwestern Law Review, 93, 631-707. http://dx.doi.org/10.2139/ssrn.142833

Cornett, M., Marcus, A., Saunders, A., \& Tehranian, H. (2007). The impact of institutional ownership on corporate operating performance. Journal of Banking \& Finance, 31, 1771-1794. http://dx.doi.org/10.1016/j.jbankfin.2006.08.006

Davis, P., \& Steil, B. (2001). Institutional Investors. MIT Press, Cambridge MA. Journal of International Review of Economics \& Finance, 12(1), 145-147.

Del Guercio, D., \& Hawkins, J. (1999). The motivation and impact of pension fund activism. Journal of Financial Economics, 52, 293-340. http://dx.doi.org/10.1016/S0304-405X(99)00011-2

Demsetz, H. (1983). The Structure of Ownership and the theory of the Firm. The Journal of Law and Economics, 26(2), 375-390. http://dx.doi.org/10.1086/467041

Demsetz, H., \& Lehn, K. (1985). The Structure of Corporate Ownership: Causes and Consequences. Journal of Political Economy, 93(6), 1155-1177. http://dx.doi.org/10.1086/261354

Demsetz, H., \& Villalonga, B. (2001). Ownership structure and corporate performance. Journal of Corporate Finance, 7, 209-233. http://dx.doi.org/10.1016/S0929-1199(01)00020-7

Fauzi, F., \& Locke, S. (2012). Board Structure, Ownership Structure and firm Performance: A study of NEW ZEALAND listed-firms. Asian Academy of Management Journal of Accounting and Finance (AAMJAF), $8(2), 43-67$.

Fazlzadeh, A., Hendi, A., \& Mahboubi, K. (2011). The Examination of the Effect of Ownership Structure on firm Performance in listed firms of Tehran Stock Exchange based on the Type of the industry. International Journal of Business and Management, 6(3), 249-266. http://dx.doi.org/10.5539/ijbm.v6n3p249

Federal Reserve Financial Economists Roundtable. (1998). Statement on Institutional Investors and Corporate Governance.

Gilson, R., \& Roe, M. (1993). Understanding the Japanese keiretsu: Overlaps between corporate governance and industrial organization. Yale Law Journal, 102, 871-906. http://dx.doi.org/10.2307/796835

Grossman, S., \& Hart, O. (1980). Takeover bids, the free rider problem, and the theory of the corporation. Bell 
Journal of Economics, 11, 42-64. http://dx.doi.org/10.2307/3003400

Hartzell, J., \& Starks, L. (2003). Institutional investors and executive compensation. The Journal of Finance, 58(6), 2351-2374. http://dx.doi.org/10.1046/j.1540-6261.2003.00608.x

Healy, J. (2003). Corporate governance \& shareholder value: Challenges facing New Zealand. Palmerton North: Dunmore.

Hu, Y., \& Izumida, S. H. (2008). The Relationship between Ownership and Performance: A Review of Theory and Evidence. International Business Research, 1(4), $72-78$.

Jensen, M. C., \& Meckling, W. H. (1976). Theory of the Firm: Managerial Behavior, Agency Costs and Ownership Structure. Journal of Financial Economics, 4, 305-360. http://dx.doi.org/10.1016/0304b405X(76)90026-X

Joher, H., Ali, M., \& Nazul. (2006). The Impact of Ownership Structure on Corporate Debt Policy two stage least square simultaneous model approach for post crisis period evidence from Kwala Lumpur stock exchange. International Business and Economics Research Journal, 5(5), 51-63.

Kochhar, R., \& David, P. (1996). Institutional investors and firm innovation: A test of competing hypotheses. $\begin{array}{lllll}\text { Strategic } & \text { Management } & \text { Journal, } & \text { 73-84. }\end{array}$ http://dx.doi.org/10.1002/(SICI)1097-0266(199601)17:1<73::AID-SMJ795>3.0.CO;2-N

La Porta, R., Lopez-De-Silanes, F., \& Shleifer, A. (1999). Corporate ownership around the world. Journal of Finance, 54, 471-518. http://dx.doi.org/10.1111/0022-1082.00115

Lee, S. (2008). Ownership Structure and Financial Performance: Evidence from Panel Data of South Korea. University of Utah, Department of Economics, Working Paper No. 17.

Maug, E. (1998). Large shareholders as monitors: Is there a trade-off between liquidity and control? Journal of Finance, 53, 65-98. http://dx.doi.org/10.1111/0022-1082.35053

McConnell, J. J., \& Servaes, H. (1990). Additional evidence on equity ownership and corporate value. Journal of Financial Economics, 27, 595-612. http://dx.doi.org/10.1016/0304-405X(90)90069-C

Nesbitt, S. (1994). Long-Term Rewards from Shareholder Activism: A Study of the CalPERS Effect. Journal of Applied Corporate Finance, 75-80. http://dx.doi.org/10.1111/j.1745-6622.1994.tb00251.x

Pound, J. (1988). Proxy contests and the efficiency of shareholder oversight. Journal of Financial Economics, 20, 237-265. http://dx.doi.org/10.1016/0304-405X(88)90046-3

Roe, M. (1994). Strong mangers, weak owners: The political roots of American corporate finance. Princeton, NJ: Princeton University Press.

Sanchez-Ballesta, J., \& Garcia-Meca, E. (2007). A Meta analytic Vision of the Effect of Ownership Structure on $\begin{array}{lllll}\text { Firm Performance. } & \text { Corporate }\end{array}$ http://dx.doi.org/10.1111/j.1467-8683.2007.00604.x

Shleifer, A., \& Vishny, R. (1986). Large shareholders and corporate control. Journal of Political Economy, 94, 448-461. http://dx.doi.org/10.1086/261385

Shleifer, A., \& Vishny, R. (1997). A survey of corporate Governance. The Journal of Finance, (2). http://dx.doi.org/10.1111/j.1540-6261.1997.tb04820.x

Wellalage, N. H., \& Locke, S. (2012). Ownership structure and firm financial performance: Evidence from panel data in Sri Lanka. Journal of Business Systems, Governance \& Ethics, 7(1), 52-65.

\section{Copyrights}

Copyright for this article is retained by the author(s), with first publication rights granted to the journal.

This is an open-access article distributed under the terms and conditions of the Creative Commons Attribution license (http://creativecommons.org/licenses/by/3.0/). 